\title{
Comparison between various DNA sterilization procedures applied in forensic analysis
}

\author{
Noora R. Al-Snan ${ }^{*+}$ (i) and Najib M. Alraimi ${ }^{\dagger}$
}

\begin{abstract}
Background: The advanced sensitive STR kits applied in forensic DNA typing techniques can cause challenging issues when evidence samples are contaminated with minute quantities of DNA from another source such as forensic analysts or crime scene examiners.

Results: In this study, laboratory air and surfaces, gloves, tools, and equipment were evaluated as potential sources of contaminating DNA. Different sterilization methods were tested for their ability to efficiently eliminate DNA in a sample. Inactivation methods included 10\% bleach, ethanol, UV light, and DNA-ExitusPlus IF. Exposure to the different inactivation protocols for varying periods of time was performed in two lab settings: low template DNA and DNA database labs. Surfaces were swabbed and any adhering DNA was quantified using HID real-time PCR. Results were detected using HID Real-Time PCR Analysis Software v1.2 and GeneMapper ID-X Software v1.4.

Conclusions: It was concluded that most of the DNA decontamination methods are not suitable for highly sensitive and precision STR kits such as GlobalFiler PCR Amplification Kit. The most suitable tested method was using DNAExitusPlus IF with the incubation time increased from 10 to $15 \mathrm{~min}$.
\end{abstract}

Keywords: DNA decontamination, DNA-ExitusPlus IF, Contamination, Sterilization, Forensic analysis, DNA evidence

\section{Background}

Forensic casework subjected to DNA analysis is now common in crime laboratories and is used to make crucial decisions in intelligence and justice. Errors such as DNA transfer and contamination may occur, and they can have serious consequences (Kloosterman et al. 2014). DNA contamination is one of the most common causes of faults (Basset and Castella 2019). Three types of DNA contamination can occur: (1) internal contamination between the samples and the DNA analysts, (2) crosscontamination between evidence of same case or different cases, and (3) external contamination which happens

\footnotetext{
*Correspondence: nr.alsnan@interior.gov.bh

${ }^{\dagger}$ Noora R. Al-Snan and Najib M. Alraimi contributed equally to the article. Forensic Science Laboratory, Directorate of Forensic Science, General Directorate of Criminal Investigation and Forensic Science, Ministry of Interior, Manama, Kingdom of Bahrain
}

between the DNA samples and the police force or crime scene experts or manufacturers of reagents or consumables (Kloosterman et al. 2014). Sometimes it is difficult to consider and interpret the police DNA match if it is a true match or a contamination, which deteriorates the judicial evidence. A near match/non-match error is defined as an event that has the potential to lead to the reporting of a wrongful match/non-match. There is an increase amount of DNA contamination due to human errors and unawareness of investigators during handling of samples. Furthermore, with the current sensitivity of profiling STR kits, preventing background DNA and contamination events from police or experts analyzing crime scene samples is becoming more challenging (Westen et al. 2009; Ballantyne et al. 2013). The police contamination can mask the true match in the DNA evidence thus causing loss of significant leads (Basset and Castella 2019; Lapointe et al. 2015). An inconsistency in 
forensic DNA analysis can lead to poor investigative or legal decisions with far-reaching implications, with the arrest of innocent suspects, the exoneration of convicted suspects, or the failure to identify criminals (Possley et al. 2004). Defining, recording, and reporting error rates have long been considered beneficial in other scientific fields, which have emphasized the need to establish protocols and guidelines to improve and develop good practices for crime scene and forensic laboratory experts (Lapworth and Teal 1994). Also, it is always mandatory to sustain the trust and good reputation of forensic parties such as the crime labs and crime scenes investigators (Basset and Castella 2019). Several procedures have recently been described to minimize the incidence of DNA contamination at the crime scene and in the laboratory (Ballantyne et al. 2013; Oorschot RAv, Found B, Ballantyne KN. 2015; Fonneløp et al. 2016). Some of these procedures are wellsuited to the laboratory setting. These include (1) staff awareness about contamination; (2) the proper use of personal protective equipment (PPE); (3) limiting access to the laboratory working area; (4) effective cleaning and sterilization of all equipment and laboratory zones (Arena 2010); (5) physical separations between offices, laboratories, or storage facilities to reduce DNA contamination; and (6) the distribution of specific activities (e.g., trace collection) among different people to disrupt contamination chains (Ballantyne et al. 2013; Oorschot RAv, Found B, Ballantyne KN. 2015; Fonneløp et al. 2016). Understanding the causes of contamination events provides the most insight into preventing them and preserving the integrity of forensic evidence (Balk 2015). Previously, different DNA sterilization was explained, such as UV irradiation. However, with the use of the PCR technique, which has become a powerful and very sensitive tool in a wide range of research, false-positive PCR results due to various types of contamination are easily detected (Preuße-Prange et al. 2009).

In this paper, we have compared various DNA decontamination techniques which are applied in international crime labs and crime scenes worldwide. We identified the most suitable DNA sterilization method to ensure minimum level of DNA transfer or cross-contamination between the police workers/DNA analysts and the DNA evidence. In some cases, we have used commercially available decontamination products but have modified manufacturer's recommended protocols to give maximum effectiveness in eliminating unwanted DNA. DNA sterilization methods tested included exposure of items harboring DNA to various concentrations of ethanol, exposure for varying periods to ultraviolet light (UV) light, exposure to $10 \%(\mathrm{v} / \mathrm{v})$ bleach (hypochlorite), and exposure to the commercially available product DNAExitusPlus IF (PanReac AppliChem, Germany) and 10\% (v/v) Clorox bleach (equivalent to $\sim 0.55 \%$, w/v, solution of sodium hypochlorite) to display the results and to elucidate the DNA transfer incidence by the police force.

\section{Methods \\ Experimental design}

Different experiments were designed to assess DNA sterilization methods such as decontamination using 10\% bleach solution, ethanol solution, and DNA-ExitusPlus IF (PanReac AppliChem, Germany) in two different DNA laboratory settings, i.e., low template DNA lab and reference DNA lab (abbreviated as CW and DB respectively) as shown in Table 1. In this study, we tested various approaches to remove DNA from hard laboratory surfaces and instruments. We applied gDNA of $\sim 20 \mathrm{ng} / \mathrm{ul}$ in clean surfaces as a control to show the effectiveness of the sterilization procedures. The DNA was dried and left for $15 \mathrm{~min}$ before any treatment. The collection of cells was done using duplicate cotton swabs (SceneSafe, UK). All research was performed in accordance with relevant guidelines/regulations as per for standard operating procedures (SOPs). The research ethics and consent were provided from the Ministry of Interior (MOI).

\section{Applying $85 \%$ ethanol solution to disinfect the working area surfaces and instruments}

Applying $85 \%$ ethanol solution to sterilize surface of widely used instruments and working areas such as thermomixers (Eppendorf, Germany), drawers and pipettors in both CW and DB labs. Each instrument was first preswabbed as a control, then applied the $85 \%$ ethanol solution to check the effectiveness.

\section{Applying 85\% ethanol solution and DNA-ExitusPlus IF to disinfect working area surfaces and instruments} Applying 85\% ethanol solution and DNA-ExitusPlus IF (PanReac AppliChem, Germany) to sanitize surfaces of working areas such as DNA extraction benches and PCR cabinets in both CW and DB labs. Each instrument was first pre-swabbed as control then applied the $85 \%$ ethanol solution and DNA-ExitusPlus IF then swabbed again to check the effectiveness

\section{Applying different exposure time of $U V$ light to disinfect $P C R$ cabinets}

By applying different exposure time of UV light to decontaminate the PCR cabinets using the following time intervals: $5 \mathrm{~min}, 10 \mathrm{~min}, 15 \mathrm{~min}, 20 \mathrm{~min}$ and $25 \mathrm{~min}$. The first DNA sample was applied as a control, then each part was swabbed in different time intervals to test the effectiveness of UV light. 
Table 1 The experimental design

\begin{tabular}{ll}
\hline Sr. No & Experiments \\
\hline 1 & $\begin{array}{l}\text { Disinfecting the working area surfaces and instruments with } 85 \% \\
\text { ethanol solution }\end{array}$
\end{tabular}

Disinfecting the working area surfaces and instruments with 85\% ethanol solution and DNA-ExitusPlus IF

3 Disinfecting the PCR cabinets using different exposure time of UV light

4 Disinfecting the working area using different exposure time of DNAExitusPlus IF

Disinfecting the working area using different concentrations of ethanol solution

7 DNA testing of gloves during work Talking in the presence of an open tube.

\section{Details}

This experiment was done to show the effectiveness of applying 85\% ethanol solution to surfaces. Method: This is a screening test; therefore, all the surfaces were swabbed for touch DNA, then $85 \%$ ethanol solution was applied. Finally, the surfaces were swabbed. Number of samples collected: a total of 12 replicate cotton swabs for pre- and post-cleaning of the thermomixer surfaces.

This experiment was done to show the effectiveness of applying both 85\% ethanol solution and DNA-ExitusPlus IF to surfaces. Method: This is a screening test; therefore, all the surfaces were swabbed for touch DNA, then both $85 \%$ ethanol solution and DNA-ExitusPlus IF were applied. Finally, the surfaces were swabbed. A number of samples collected: a total of 24 replicate cotton swabs for pre- and post-cleaning of different surfaces of benches, cabinets, drawers, and tools.

This experiment was done to show the effectiveness of using different exposure times of UV irradiation to samples. Method: Here, we have applied saliva ( $20 \mathrm{ng} / \mathrm{ul})$ in different surfaces and then we have swabbed each spot in different timings. Number of samples collected: a total of 12 replicate cotton swabs for each time exposure on the working area of PCR cabinets.

This experiment was done to show the effectiveness of using different exposure time of DNA-ExitusPlus IF to samples. Method: Here, we have applied saliva $(\sim 20 \mathrm{ng} / \mathrm{ul})$ in different surfaces and then we have swabbed each spot in different timings. Number of samples collected: a total of 6 replicate cotton swabs for each time exposure in DNA collection benches.

This experiment was done to show the effectiveness of using different exposure times of bleach to samples. Method: Here, we have applied first saliva $(\sim 20 \mathrm{ng} / \mathrm{ul})$ in different surfaces and then we have swabbed each spot in different timings. Number of samples collected: a total of 14 replicate cotton swabs for each time exposure in DNA collection benches.

This experiment was done to show the effectiveness of using different concentrations of ethanol solution to samples. Method: Here, we have applied saliva $(\sim 20 \mathrm{ng} / \mathrm{ul})$ in different surfaces and then we have swabbed each spot in different concentrations. Number of samples collected: a total of 10 replicate cotton swabs for each concentration in DNA collection benches.

This experiment was designed to check the possibility of DNA transfer using gloves during work. Method: This is a screening test, in which different used gloves were swabbed during their lab work. Number of samples collected: a total of 6 replicate cotton swabs for each glove

This experiment was done to detect any possibilities for DNA contamination in pre- and post-PCR working area. Method: tubes containing DNA extract was used to talk while the tubes were open, in pre- and post-PCR procedures without wearing masks. Number of samples collected: a total of 8 replicate tubes for each experiment.

In this experiment, it was designed to check if the air contains any DNA. Method: swabs were taken from air by moving the air around different locations. Number of samples collected: a total of 10 replicate cotton swabs for each location.

\section{Applying different exposure time of DNA-ExitusPlus IF to disinfect working area}

By applying different exposure time of DNA-ExitusPlus IF (PanReac AppliChem, Germany) to decontaminate the working area using the following time intervals: $10 \mathrm{~min}$ and $15 \mathrm{~min}$. To ensure proper decontamination, we have applied DNA on the tested surfaces and swabbed part of DNA as a control, then sprayed the solution then waited for the studied time then swabbed again to check for efficiency.

\section{Applying different exposure time of bleach to disinfect working area}

By applying different exposure time of $10 \%$ bleach solution (commercially available) to decontaminate the working area using the following time intervals: $10 \mathrm{~min}$, 
$15 \mathrm{~min}, 20 \mathrm{~min}, 25 \mathrm{~min}, 30 \mathrm{~min}$, and $35 \mathrm{~min}$. To ensure proper decontamination, we have applied DNA on the tested surfaces and swabbed part of DNA as a control, then sprayed the solution then waited for the studied time then swabbed again to check for efficiency.

\section{Applying different concentrations of ethanol solution to disinfect working area}

By applying different concentrations of ethanol solution to decontaminate the working area using the following concentrations: $70 \%, 75 \%, 80 \%$, and $85 \%$. To ensure proper decontamination, we have applied DNA on the tested surfaces and swabbed part of the DNA as a control, then sprayed the ethanol solution using the abovementioned concentrations and waited for $10 \mathrm{~min}$ and then swabbed again each part to check for efficiency of using different ethanol concentration

\section{DNA testing of gloves during work}

Random swabbing was done during DNA testing for different DNA experts to show the possibility of DNA transfer during work. Each of the three gloves was swabbed using duplicate cotton swabs.

\section{Talking in the presence of an open tube}

We have talked and coughed inside DNA test tubeswithout wearing masks-prior to proceed for pre and post PCR amplification to study the effect of DNA contamination from unprocessed DNA such as the saliva. The procedure was done in pre- and post-PCR cabinets. The time of exposure was $10 \mathrm{~s}$ for each tube.

\section{Presence of DNA in the air}

Random swabbing was done in the air to check for the presence of DNA in the air such as saliva particles. Different areas were swabbed using duplicate cotton swabs such as working areas, PCR cabinets, and offices for CW and DB labs. The time of exposure was $10 \mathrm{~s}$ for each area.

Table 1 summarizes the methods applied to show the effectiveness of DNA sterilization and the presence of different DNA contamination in laboratory.

\section{DNA processing}

Genomic DNA (gDNA) were extracted from the collected cotton swabs samples (SceneSafe, UK) using AutoMate Express DNA Extraction System (Thermo fisher Scientific, Inc., Waltham, MA, USA) following magnetic beads principle in $50 \mu$ l elution volume (Davis et al. 2012). In each procedure, unused cotton swab was extracted as a negative control and another buccal swab from a DNA analyst was used as a positive control.

Subsequently, the extracted DNAs were quantified using Quantifiler HP DNA Quantification Kit (Thermo
Fisher Scientific, Inc., Waltham, MA, USA) in the 7500 Real-Time PCR System (Thermo Fisher Scientific, Inc., Waltham, MA, USA) according to manufacturer's recommendation (Holt et al. 2016). The kit can reproducibly quantify $5 \mathrm{pg} / \mu \mathrm{L}$ of human genomic DNA in a sample and can quantify DNA concentrations from 0.005 to $>50$ $\mathrm{ng} / \mathrm{uL}$. About $1.2 \mathrm{ng}$ of the extracted DNA $(15 \mu \mathrm{l})$ was amplified using GlobalFiler PCR Amplification Kit in total of $25 \mu \mathrm{l}$ reaction volume (Thermo Fisher Scientific, Inc., Waltham, MA, USA) according to manufacturer's recommendation (Ludeman et al. 2018).

A total of 24 loci were amplified, including 21 autosomal STR loci and three gender determination loci in 29 cycles via MicroAmp Optical 96-Well Reaction Plate (Thermo Fisher Scientific Company, Carlsbad, USA) along with the previously genotyped male control (provided with the kit) and low TE buffer as a negative control using 96-Veriti thermal cycler (Thermo Fisher Scientific Company, Carlsbad, USA). The PCR products $(1 \mu \mathrm{l})$ were separated by capillary electrophoresis in an ABI 3500xl Genetic Analyzer (Thermo Fisher Scientific Company, Carlsbad, USA) with reference to the LIZ600 size standard v2 (Thermo Fisher Scientific, Inc., Waltham, MA, USA) in total of $10 \mu \mathrm{l}$ master mix consisting of LIZ600 size standard and Hi-Di formamide (Thermo Fisher Scientific, Inc., Waltham, MA, USA). GeneMapper ID-X Software v1.4 (Thermo Fisher Scientific, Inc., Waltham, MA, USA) was used for genotype assignment (Ludeman et al. 2018).

\section{Analysis}

The results from the 7500 Real-Time PCR System (Thermo Fisher Scientific, Inc., Waltham, MA, USA) were detected using the HID Real-Time PCR Analysis Software v1.2. All the results were input in a table format. Additionally, the STR profiles were analyzed and interpreted using GeneMapper ID-X Software v1.4 (Thermo Fisher Scientific, Inc., Waltham, MA, USA) by direct counting the number of loci/peaks found in the STR profiles and inserted in the table format.

RFU for reference samples were done using in house validation for the GlobalFiler Amplification Kit to differentiate between the stochastic threshold and possible allele drop out (Al-Snan et al. 2019).

\section{Results}

\section{DNA quantification}

The results obtained from the HID Real-Time PCR Analysis Software v1.2 displayed the amount of DNA using the small autosomal (SA) human target available in the Quantifiler HP DNA Quantification Kit (Thermo Fisher Scientific, Inc., Waltham, MA, USA). SA consists of relatively short amplicons (75 to 80 bases) to improve the 
detection of degraded gDNA. As shown in Table 2, the detection of gDNA in several experiments conducted with $R$-squared $\left(R^{2}\right)$ values equal to 0.998 and 1.0 defining perfect predictive accuracy. Overall, it is evident that applying ethanol sterilization to the working benches and instruments did decontaminate the presence of gDNA but did not sterilize to the optimal level. However, there was some remains of gDNA found on the instruments and benches. With examining different concentration of ethanol disinfection used, it was clearly concluded that $85 \%$ ethanol was the best for sterilization. Yet, using exclusively $85 \%$ ethanol solution for sterilization did not completely sterilize the working area. Secondly, when using UV light for PCR cabinet decontamination, different time exposure was conducted to the induced contamination to show if 15-min exposure was the optimum as recognized in international instructions for many user guides. Nevertheless, it was found out that exposing the gDNA to the UV light even after 25 min did not totally sterilize the PCR cabinets from the presence of gDNA, particularly when amplifying the DNA using overly sensitive amplification kits such as GlobalFiler PCR Amplification Kit. Therefore, using solely UV light to decontaminate the PCR cabinets was not sufficient for any DNA testing labs. Subsequently, various time exposure of $10 \%$ bleach solution was tested to show the ideal time for gDNA sterilization using the bleach.

It was noticed that most of the used timings were undetermined (Table 2) as the $10 \%$ bleach may possibly interfere with the proper interpretation of results. Therefore, STR profiles were required to give reliable results.

DNA-ExitusPlus IF (PanReac AppliChem, Germany) was used additionally to test its effectiveness for DNA sterilization in the forensic laboratory. The recommended time exposure of the solution is $10 \mathrm{~min}$ based on the user guide. However, we have noticed that increasing the time expose of gDNA with the solution up to 15 min gave the optimal DNA sterilization results. Further, DNA-ExitusPlus IF sterilization was combined along with $85 \%$ ethanol to illustrate if the combination of the treatments may possibly increase the level of sterilization. In some cases, the gDNA detection was less after the application of DNA-ExitusPlus IF (Table 2); in other cases, it remained the same. Overall, the DNA-ExitusPlus IF showed the most effective method in DNA sterilization and decontamination of working area, instruments, and tools.

In second part of the experiments, we have examined the presence of DNA on the gloves while DNA analysts performed DNA testing. All the random swabbing of the equipped gloves gave detection of gDNA on the exterior surfaces of the gloves, which gave an ideal justification for having DNA transfer and cross-contamination between forensic cases. The DNA analysts were using $85 \%$ ethanol to wipe the worn gloves during work instead of replacing the gloves with new ones. Additionally, we have demonstrated if talking in the presence of an open tube may possibly cause DNA contamination in two steps: pre- and post-PCR steps. However, all the tested samples gave negative detection of gDNA ( $0.0002 \mathrm{ng} / \mathrm{ul})$, which clarifies that it was nearly impossible to cause DNA transfer to the extracted DNA tubes and it was safe to perform DNA amplification and detection steps without the need to use masks to protect the samples from contamination.

Finally, we have performed random waving a clean swab in the air for $30 \mathrm{~s}$ to show the presence of DNA in different premises. As shown in Table 2, there was variations of gDNA detection, with maximum results in the staff office room in the CW DNA lab with the value of $\sim 0.0045 \mathrm{ng} / \mathrm{ul}$ (the office was crowded with more than six DNA analysts in $3 \times 3 \mathrm{~m}$ room), and it was clear that there are very few gDNA detection in the air.

\section{STR profiles}

To assist the results obtained from the HID Real-Time PCR Analysis Software v1.2, STR profiles were generated for all the samples to study the consistency of the outcomes. Most of the STR profiles obtained after disinfection with the ethanol-regardless of its concentration-retained some of the loci. As shown in Fig. 1, some of the different loci found which may possibly cause contamination to the original DNA found in the forensic cases. The rest of loci were excluded in the figure as they were blank (for the sake of spacing).

Regarding different time exposure to the UV light, we have studied different exposures in terms of 5 to $25 \mathrm{~min}$ using 5-min time intervals. As shown in Fig. 2, the DNA quantity is declining by increasing the time exposure with the UV light. Yet in $25 \mathrm{~min}$ still the Y indel locus was observed (1 insertion/deletion polymorphic marker on the $\mathrm{Y}$ chromosome), which might interfere with the original DNA found in evidence.

Additionally, we have tested the DNA-ExitusPlus IF to decontaminate the instruments and working areas in two different timings (10 and $15 \mathrm{~min}$ ). It was recommended by the manufacturer to use $10 \mathrm{~min}$ to perform DNA sterilization. Yet, $10 \mathrm{~min}$ was not sufficient to have proper disinfection. The optimal timing was $15 \mathrm{~min}$ as shown in Fig. 3.

Furthermore, we have tested different equipped nitrile gloves during DNA testing from three random DNA analysts. All the worn gloves gave DNA profiles when swabbed. In Fig. 4, the generated STR profiles from different gloves which emphasized on the importance of replacing gloves with new pair instead of spraying ethanol to the gloves. 
Table 2 The detection of gDNA from different experiments obtained through HID Real-Time PCR Analysis Software v1.2

\begin{tabular}{|c|c|c|c|c|}
\hline Sr. No & Experiment details & \multicolumn{2}{|c|}{$\begin{array}{l}\text { Amount of gDNA (ng/ul) } \\
\text { (mean) }\end{array}$} & ${ }^{* *} \mathrm{Ct}$ values (mean) \\
\hline \multicolumn{5}{|c|}{ 1) Disinfecting the working area surfaces and instruments with $85 \%$ ethanol solution } \\
\hline 1 & Thermomixers (1), DNA CW lab & Precleaning: 0.002 & Post-cleaning: 0.0004 & $31.5,33.8$ \\
\hline 2 & Thermomixers (2), DNA CW lab & Precleaning: 0.0021 & Post-cleaning: 0.0022 & $31.4,31.3$ \\
\hline 3 & Thermomixers (3), DNA DB lab & Precleaning: 0.0015 & Post-cleaning: 0.0023 & $31.9,31.2$ \\
\hline \multicolumn{5}{|c|}{ 2) Disinfecting the working area surfaces and instruments with $85 \%$ ethanol solution and DNA-ExitusPlus IF } \\
\hline 4 & Bench inside the DNA extraction room, DNA CW lab & \multicolumn{2}{|c|}{ Precleaning:0.0052, post-cleaning ethanol:0.0035, Post-cleaning DNA-exitus: 0.0005} & $33.39,30.2,30.76$ \\
\hline 5 & PCR cabinet, DNA CW lab & \multicolumn{2}{|c|}{ Precleaning:0.0041, post-cleaning ethanol:0.0003, post-cleaning DNA-exitus: 0.0003} & $30.54,34.28,34.34$ \\
\hline 6 & PCR cabinet, DNA DB lab & Precleaning: 0.0011 & Post-cleaning DNA-exitus: *UD & $32.34, U D$ \\
\hline 7 & PPE drawer, DNA DB lab & Precleaning: 0.0013 & Post-cleaning ethanol: 0.0006 & $33.11,32.14$ \\
\hline 8 & 1000ul pipettes, DNA CW lab & Precleaning: 0.061 & Post-cleaning ethanol: 0.0004 & $3.74,26$ \\
\hline \multicolumn{5}{|c|}{ 3) Disinfecting the PCR cabinets using different exposure times of UV light } \\
\hline 9 & Induced contamination, UV light, 0 min, control & 0.0081 & & 33.54 \\
\hline 10 & Exposure UV light, 5 min & 0.0045 & & 34.36 \\
\hline 11 & Exposure UV light, $10 \mathrm{~min}$ & 0.0063 & & 33.89 \\
\hline 12 & Exposure UV light, 15 min & 0.0009 & & 36.65 \\
\hline 13 & Exposure UV light, 20 min & 0.0024 & & 35.32 \\
\hline 14 & Exposure UV light, $25 \mathrm{~min}$ & 0.0018 & & 35.61 \\
\hline \multicolumn{5}{|c|}{ 4) Disinfecting the working area using different exposure times of DNA-ExitusPlus IF } \\
\hline 15 & Induced contamination, DNA-Exitus, 0 min, control & 0.0507 & & 35.41 \\
\hline 16 & Post-cleaning, DNA-Exitus, 10 min & 0.0011 & & 34.41 \\
\hline 17 & Post-cleaning, DNA-Exitus, 15 min & UD & & 36.35 \\
\hline \multicolumn{5}{|c|}{ 5) Disinfecting the working area using different exposure times of bleach } \\
\hline 18 & Induced contamination, bleach, 0 min, control & 0.0845 & & 33.12 \\
\hline 19 & Post-cleaning, bleach, $10 \mathrm{~min}$ & UD & & UD \\
\hline 20 & Post-cleaning, bleach, 15 min & 0.0002 & & 34.41 \\
\hline 21 & Post-cleaning, bleach, 20 min & UD & & UD \\
\hline 22 & Post-cleaning, bleach, 25 min & UD & & UD \\
\hline 23 & Post-cleaning, bleach, $30 \mathrm{~min}$ & UD & & UD \\
\hline 24 & Post-cleaning, bleach, 35 min & 0.0003 & & 36.35 \\
\hline \multicolumn{5}{|c|}{ 6) Disinfecting the working area using different concentrations of ethanol solution } \\
\hline 25 & Induced contamination, ethanol, $0 \%$, control & 0.0096 & & 27.05 \\
\hline 26 & Post-cleaning, ethanol, 70\% & 0.0045 & & 30.4 \\
\hline 27 & Post-cleaning, ethanol, $75 \%$ & 0.0038 & & 30.63 \\
\hline 28 & Post-cleaning, ethanol, $80 \%$ & 0.0043 & & 30.46 \\
\hline 29 & Post-cleaning, ethanol, 85\% & 0.0017 & & 30.17 \\
\hline \multicolumn{5}{|c|}{ 7) DNA testing of gloves during work } \\
\hline 30 & Random swabbing glove 1 & 0.0022 & & 31.36 \\
\hline 31 & Random swabbing glove 2 & 0.0033 & & 30.82 \\
\hline 32 & Random swabbing glove 3 & 0.0022 & & 31.38 \\
\hline \multicolumn{5}{|c|}{ 8) Talking in the presence of an open tube } \\
\hline 33 & Talking inside DNA tube, pre-PCR 1 & UD & & UD \\
\hline 34 & Talking inside DNA tube, pre-PCR 2 & 0.0002 & & 34.91 \\
\hline 35 & Talking inside DNA tube, post-PCR 1 & 0.0006 & & 33.27 \\
\hline 36 & Talking inside DNA tube, post-PCR 2 & 0.0002 & & 34.51 \\
\hline \multicolumn{5}{|c|}{ 9) Presence of DNA in the air } \\
\hline 37 & Air swabbing, staff office, CW lab & 0.0045 & 30.38 & \\
\hline 38 & Air swabbing, DNA extraction room, CW lab & 0.0003 & 34.34 & \\
\hline 39 & Air swabbing, staff office, DB lab & 0.0012 & 32.21 & \\
\hline 40 & Air swabbing, PCR cabinet, CW lab & UD & UD & \\
\hline 41 & Air swabbing, PCR cabinet, DB lab & UD & UD & \\
\hline
\end{tabular}

*UD Underdetermined, ${ }^{* *}$ Ct values Cycle Threshold.

$R^{2}$ values: 0.998 and 1.0 

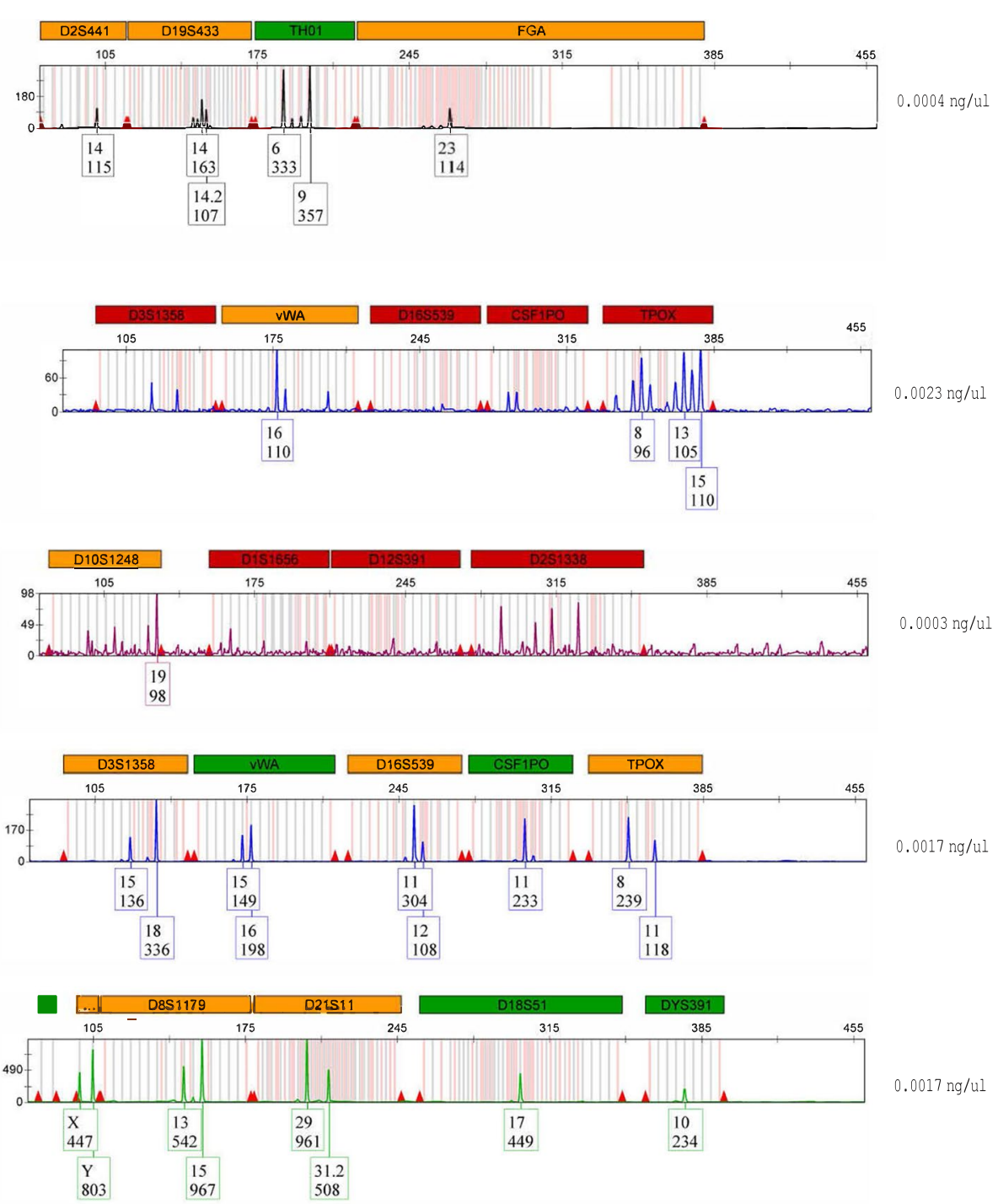

Fig. 1 STR profiles generated from post-sterilization with different concentrations of ethanol

Moreover, we have tested the effect of $10 \%$ bleach in DNA sterilization as it is widely used in DNA testing labs. Different time exposures were investigated in 5-min time intervals. All the STR profiles results displayed different loci after disinfection. As shown in Fig. 5, 10\% bleach was not sufficient for proper DNA disinfection.

\section{Discussion}

There are different DNA sterilization methods, mainly the $85 \%$ ethanol, $10 \%$ bleach, UV light, and commercially available spray bottles such as DNA-ExitusPlus IF. Each of these methods is extensively used in many of the international forensic labs and crime scenes divisions to ensure proper decontamination of the premises and instruments prior to evidence examination. In this paper, we have investigated the most common DNA decontamination methods which can be applied in different fields such as forensics and law enforcements, medical, and biotechnology. DNA contamination is sporadic, which is difficult to detect and more challenging to interpret the results. Although elimination database is a good method to identify the source of contamination, it is better to avoid contamination preceding to DNA typing than to identify it after samples are processed (Gefrides et al. 2010). Inclusion of extraction and amplification negative controls is one of the methods conducted to investigate the presence of cross-contamination/consumable contamination in the DNA testing. Crime scene examiners as well as forensic analysts must equip PPE, i.e., masks, sterile suits, hair cap, gloves, 

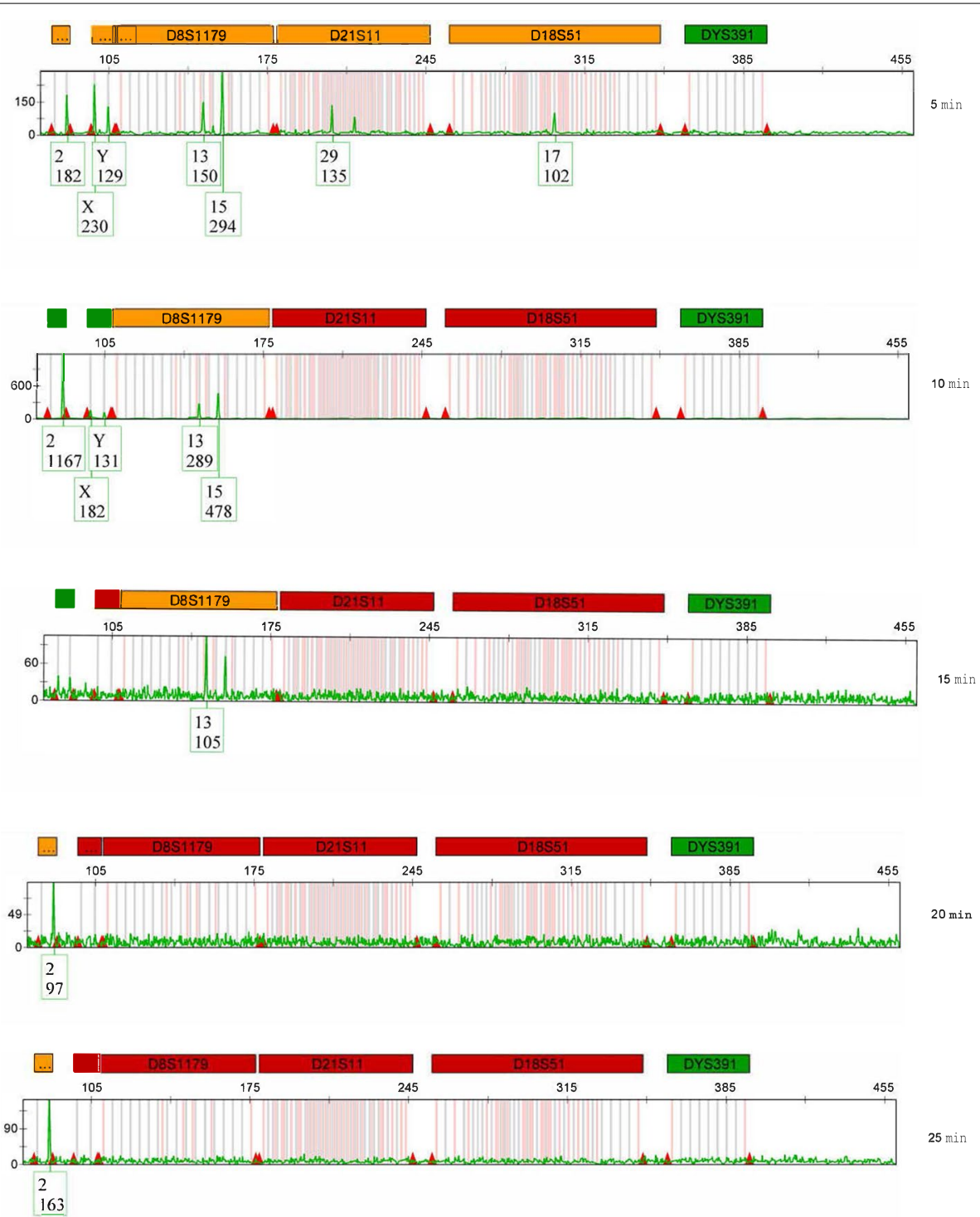

Fig. 2 The effect of UV light in DNA sterilization using different time exposure

as it greatly protects the evidence from contamination (Rutty et al. 2003). Also, gloves must be replaced with new pair instead of spraying or wiping the gloves with $85 \%$ ethanol as it is not sufficient to have a suitable decontamination.

Using HID Real-Time PCR Analysis Software v1.2 in 7500 Real-Time PCR System (Thermo Fisher Scientific, Inc., Waltham, MA, USA), $R^{2}$ values obtained indicating perfect predictive accuracy of the results offering good confidence of interpretation. A cycle threshold (Ct value) is defined as the number of amplification cycles required to reach a fixed background level of fluorescence at which the diagnostic result of the real-time PCR changes from negative (not detectable) to positive - (detectable). The amount of DNA obtained in parallel with $\mathrm{Ct}$ values (mean) refer to the level of DNA inhibition, higher $\mathrm{Ct}$ values, and more PCR cycles is required to perform which lead to presence of DNA inhibition (Sidstedt et al. 2020). For example, in UV light exposure after $15 \mathrm{~min}$, it gave $\mathrm{Ct}$ values of approximately $\sim 35$, which indicates the high level of DNA degradation from the UV light. Similarly with DNAexitus method, Ct values were above 34 in all the time exposures as it was more effective in sterilization surfaces. However, even with the $\mathrm{Ct}$ values, the STR profiles must be assessed to have a better finding of the results. 

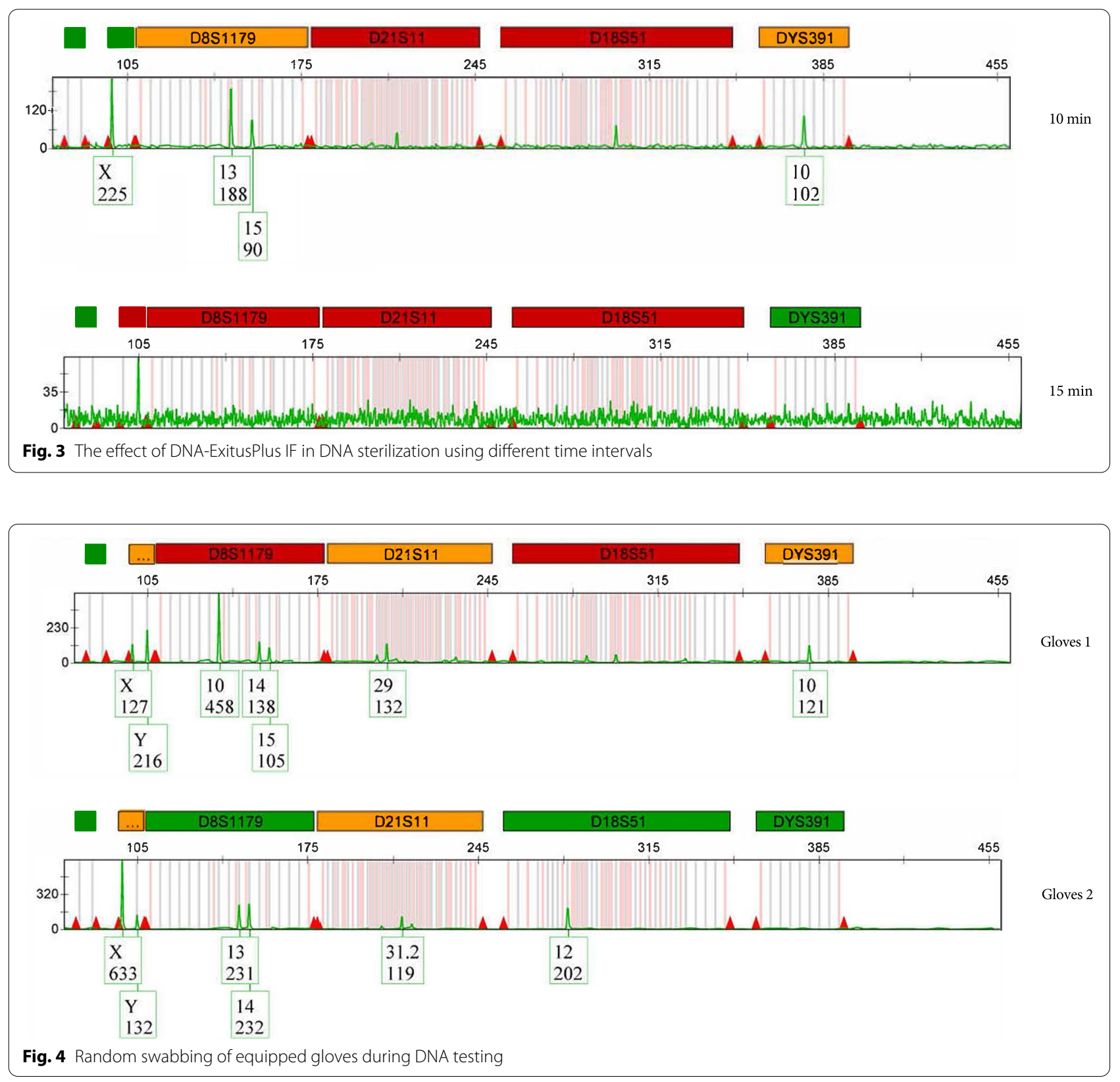

In conjunction with innovative DNA technologies, DNA amplification has an increased sensitivity that even the lowest amount of gDNA ( 0.0002 ng/ul) can be amplified. Thus, DNA sterilization methods must be an ideal solution to the advanced STR kits. As shown in Table 2, the decontamination with $85 \%$ ethanol, $10 \%$ bleach, and UV light were inadequate to have a proper sterilization. The most suitable method was using DNA-ExitusPlus IF and to incubate for 15 min instead of $10 \mathrm{~min}$ on the surfaces/instruments before wiping (Arena 2010). This method was more accurate to be used when applying sensitive amplification kits such as GlobalFiler PCR Amplification Kit (Thermo Fisher Scientific, Inc., Waltham, MA, USA). Although some papers concluded to use hypochlorite as superior solution to clean laboratory surfaces (Kampmann et al. 2017; Ballantyne et al. 2015), in this study, we have proved that hypochlorite might not be sufficient to completely decontaminate all of the loci such as $\mathrm{Y}$ indel locus found in the GlobalFiler PCR Amplification Kit which might interferes with STR interpretation. 

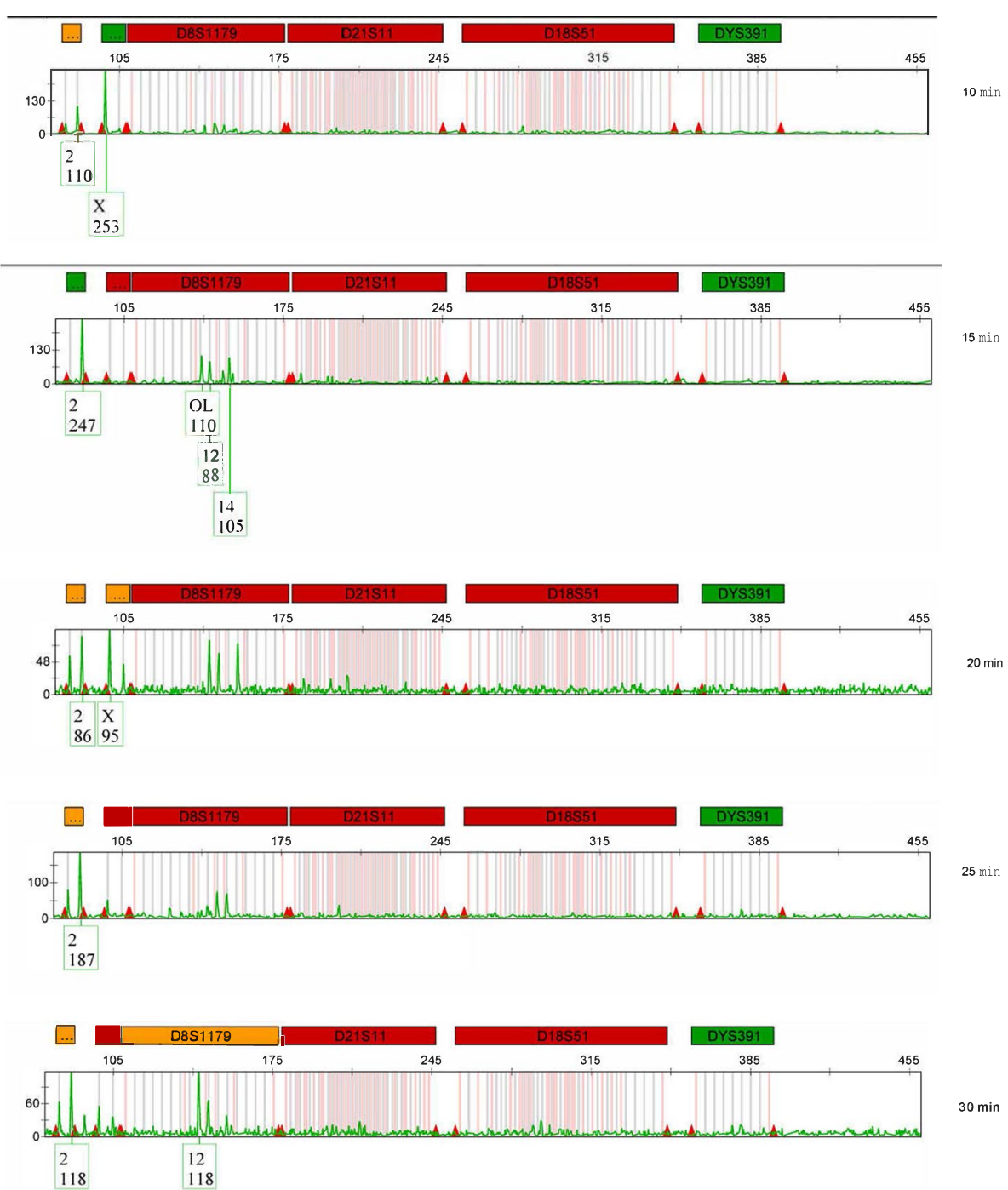

Fig. 5 The effect of 10\% bleach in performing DNA sterilization

\section{Conclusions}

In this paper, we have investigated different sources of DNA contamination in air, laboratory surfaces, gloves, and tools. Different DNA sterilization methods were applied to test the efficiency using sensitive STR kits, i.e., GlobalFiler PCR Amplification Kit.

Results showed the insufficiency of the current methods to perform complete decontamination procedures. Modified protocols were suggested for some procedures such as using DNA-ExitusPlus IF.

\section{Abbreviations}

CW: Casework lab (low DNA lab); Ct: Cycle threshold; DB: Database lab (reference DNA lab); gDNA: Genomic DNA; HID: Human identification; Min: Minutes; MOI: Ministry of interior; PPE: Personal protective equipment; R2:
R-squared; SOPs: Standard operating procedures; STR: Short tandem repeats; UV: Ultraviolet.

\section{Acknowledgements}

We would like to thank the authorities in our Forensic Science for allowing us to utilize the Forensic Science Laboratory. This research did not receive any specific grant from funding agencies in the public, commercial, or not-forprofit sectors.

\section{Authors' contributions}

Conceptualization: N.R.A; Investigation: N.R.A, N.M.A; Formal analysis: N.R.A, N.M.A; Writing - original draft preparation: N.R.A; Writing review and editing: N.R.A, N.M.A; Visualization: N.R.A, N.M.A; Supervision: N.R.A. The authors have read and approved the manuscript.

\section{Funding}

This research did not receive any specific grant from funding agencies in the public, commercial, or not-for-profit sectors. 
Availability of data and materials

The datasets generated during and/or analyzed during the current study are available within the text.

\section{Declarations}

Ethics approval and consent to participate

All the experiments conducted under the approval of MOI, Bahrain. The consent to participate was obtained from $\mathrm{MOI}$, Bahrain. The reference number is not applicable.

\section{Consent for publication}

Written informed consent to publish this information was obtained from study participant's next of kin and/or parent/legal guardian which will be available upon request. The consent for publication was obtained from MOI, Bahrain.

\section{Competing interests}

The authors declare that they have no competing interests.

Received: 25 August 2021 Accepted: 12 January 2022

Published online: 25 January 2022

\section{References}

Al-Snan NR, Messaoudi S, Babu SR, Bakhiet M (2019) Population genetic data of the 21 autosomal STRs included in GlobalFiler kit of a population sample from the Kingdom of Bahrain. PLoS One 14(8):e0220620

Arena A (2010) Dna exitus plus ${ }^{\mathrm{TM}}$ versus standard bleach solution for the removal of dna contaminants on work surfaces and tools. Investig Sci J 2(2):20-29

Balk C (2015) Reducing contamination in forensic science. Themis: Research Journal of Justice Studies and Forensic. Science. 3(1):12

Ballantyne KN, Poy AL, van Oorschot RA (2013) Environmental DNA monitoring: beware of the transition to more sensitive typing methodologies. Australian J Forensic Sci 45(3):323-340

Ballantyne KN, Salemi R, Guarino F, Pearson JR, Garlepp D, Fowler S et al (2015) DNA contamination minimisation-finding an effective cleaning method. Australian J Forensic Sci 47(4):428-439

Basset P, Castella V (2019) Positive impact of DNA contamination minimization procedures taken within the laboratory. Forensic Sci Int Genet 38:232-235

Davis CP, King JL, Budowle B, Eisenberg AJ, Turnbough MA (2012) Extraction platform evaluations: a comparison of AutoMate Express $^{\mathrm{TM}}, \mathrm{EZ} 1^{\circledR}$ Advanced $\mathrm{XL}$, and Maxwell ${ }^{\circledR} 16$ Bench-top DNA extraction systems. Legal Med 14(1):36-39

Fonneløp AE, Johannessen H, Egeland T, Gill P (2016) Contamination during criminal investigation: detecting police contamination and secondary DNA transfer from evidence bags. Forensic Sci Int Genet 23:121-129

Gefrides LA, Powell MC, Donley MA, Kahn R (2010) UV irradiation and autoclave treatment for elimination of contaminating DNA from laboratory consumables. Forensic Sci Int Genet 4(2):89-94

Holt A, Wootton SC, Mulero JJ, Brzoska PM, Langit E, Green RL (2016) Developmental validation of the Quantifiler ${ }^{\circledR} \mathrm{HP}$ and Trio Kits for human DNA quantification in forensic samples. Forensic Sci Int Genet 21:145-157

Kampmann M-L, Børsting C, Morling N (2017) Decrease DNA contamination in the laboratories. For Sci Int Genet Suppl Ser 6:e577-e578

Kloosterman A, Sjerps M, Quak A (2014) Error rates in forensic DNA analysis: definition, numbers, impact and communication. Forensic Sci Int Genet $12: 77-85$

Lapointe M, Rogic A, Bourgoin S, Jolicoeur C, Séguin D (2015) Leading-edge forensic DNA analyses and the necessity of including crime scene investigators, police officers and technicians in a DNA elimination database. Forensic Sci Int Genet 19:50-55

Lapworth R, Teal TK (1994) Laboratory blunders revisited. Ann Clin Biochem 31(1):78-84

Ludeman MJ, Zhong C, Mulero JJ, Lagacé RE, Hennessy LK, Short ML et al (2018) Developmental validation of GlobalFiler ${ }^{\mathrm{TM}}$ PCR amplification kit: a 6-dye multiplex assay designed for amplification of casework samples. Int J Legal Med 132(6):1555-1573
Possley M, Mills S, McRoberts F (2004) Scandal touches even elite labs: flawed work, resistance to scrutiny seen across US. Chi Trib 21:1

Preuße-Prange A, Renneberg R, Schwark T, Poetsch M, Simeoni E, von WurmbSchwark N (2009) The problem of DNA contamination in forensic case work - how to get rid of unwanted DNA? Forensic Sci Int Genet Suppl Ser 2(1):185-186

RAv O, Found B, Ballantyne KN (2015) Considerations relating to the components of a laboratory DNA contamination minimisation monitoring (DCMM) program. Forensic Science Policy \& Management: An. Int J 6(3-4):91-105

Rutty G, Hopwood A, Tucker V (2003) The effectiveness of protective clothing in the reduction of potential DNA contamination of the scene of crime. Int J Legal Med 117(3):170-174

Sidstedt M, Rådström P, Hedman J (2020) PCR inhibition in GPCR, dPCR and MPS - mechanisms and solutions. Anal Bioanal Chem 412(9):2009-2023

Westen AA, Nagel JH, Benschop CC, Weiler NE, De Jong BJ, Sijen T (2009) Higher capillary electrophoresis injection settings as an efficient approach to increase the sensitivity of STR typing. J Forensic Sci 54(3):591-598

\section{Publisher's Note}

Springer Nature remains neutral with regard to jurisdictional claims in published maps and institutional affiliations.

\section{Submit your manuscript to a SpringerOpen ${ }^{\circ}$ journal and benefit from:}

- Convenient online submission

- Rigorous peer review

- Open access: articles freely available online

- High visibility within the field

- Retaining the copyright to your article

Submit your next manuscript at $\boldsymbol{\nabla}$ springeropen.com 